\title{
Lower ribavirin biodisponibility in patients with HIV-HCV coinfection in comparison with HCV monoinfected patients
}

\author{
Giorgiana Hatu ${ }^{1,2 \dagger}$, François Bailly ${ }^{1,3,4+}$, Emmanuel Pourcelot ${ }^{5}$, Pierre Pradat ${ }^{1,3,4^{*}}$, Patrick Miailhes ${ }^{3,4,6}$, \\ Marianne Maynard ${ }^{1,3,4}$, François Parant ${ }^{5}$, Pierre Chiarello ${ }^{7}$, Jean-Michel Livrozet ${ }^{7}$, Fabien Zoulimm ${ }^{1,3,4}$ \\ and Marie-Claude Gagnieu ${ }^{5}$
}

\begin{abstract}
Background: In HIV infected patients, the impact of ribavirin (RBV) pharmacology on sustained virologic response (SVR) to hepatitis $\mathrm{C}$ virus (HCV) treatment has not been fully investigated. The objective of this study was to compare the early RBV plasma exposure between a population of HIV-HCV coinfected patients and an HCV monoinfected group.

Methods: Early RBV plasma exposure (expressed as Area Under the Curve (AUC) from 0 to 4 h) after a $600 \mathrm{mg}$ first dose of RBV was measured in a population of HIV-HCV coinfected patients in comparison with an HCV monoinfected group. Peripheral blood samples were collected before the $600 \mathrm{mg}$ RBV first dose (T0) to ensure no detectable baseline plasma RBV, and then $30 \mathrm{mn}, 1,2$ and 4 hours after RBV intake (T0.5, T1, T2 and T4).

Results: Eighty-six patients with chronic hepatitis C entered the study among whom 23 (27\%) were HIV-HCV coinfected. Coinfected patients had a significantly lower RBV-AUC 0-4h (median: $1469 \mu \mathrm{g}^{*} \mathrm{~h} / \mathrm{L}$ [range 936-3677]) compared with monoinfected patients (2030 $\mu \mathrm{g}^{*} \mathrm{~h} / \mathrm{L}$ [851-7700]; $\left.\mathrm{p}=0.018\right)$. This RBV under exposure in coinfected patients persisted after normalization of AUC to RBV dose per kilogram of body weight (182 $\mu g^{*} \mathrm{~h} / \mathrm{L}$ [110-425] versus $271 \mu g^{*} h / L$ [82-1091], $p=0.001$ ).

Conclusions: These results suggest that lower early bioavailability of RBV could be one of the reasons for lower SVR in HIV-HCV coinfected patients treated with pegylated interferon/RBV combination therapy. RBV plasma underexposure seems to be associated with the immunological status of the patients with lower $A \cup C_{0-4 h}$ values observed in the more immunosuppressed coinfected patients.
\end{abstract}

Keywords: Hepatitis C, Human immunodeficiency virus, Ribavirin exposure, Treatment, Coinfection

\section{Background}

Worldwide prevalence of hepatitis $\mathrm{C}$ virus (HCV) infection in human immunodeficiency virus (HIV) infected patients is about 33\%[1-3] and this pathology represents one of the main comorbidities in this population $[4,5]$. Before the use of protease inhibitors for genotype 1 $\mathrm{HCV}$ infection, combination of ribavirin (RBV) and pegylated interferon- $\alpha$ (PEG-IFN) was the standard of care for treatment of chronic $\mathrm{HCV}$ patients and it is still

\footnotetext{
*Correspondence: pierre.pradat@univ-lyon1.fr

${ }^{+}$Equal contributors

'Department of Hepatology, Hôpital de la Croix-Rousse, Hospices Civils de Lyon, 103 grande rue de la Croix-Rousse, 69004 Lyon, France

${ }^{3}$ INSERM U1052, Lyon, France

Full list of author information is available at the end of the article
}

the standard for non-1 genotype infection with or without HIV coinfection. All guidelines to adjust RBV doses have been defined in monoinfected patients but are also used in HIV-HCV ones. According to these guidelines and excepted for genotype 2 or 3 infected patients, RBV doses must be adapted to body weight [6]. Studies have shown that high RBV plasma concentrations could improve early virological response rates $[7,8]$. However, RBV daily dose, even adjusted for body weight is poorly correlated with RBV plasma concentration $[9,10]$ due to a large inter-individual variability in exposure [11-13]. Different explanations have been proposed for this variability: i) the lean body weight would be a better covariate with a linear influence on RBV clearance 
[14]; ii) RBV exposure depends on creatinine clearance [15]; iii) the RBV pharmacokinetics could be impacted by the pharmacological or pathological context of HIV-HCV coinfection [16]. Loustaud-Ratti et al., showed that RBV plasma exposure after a single dose of $600 \mathrm{mg}$ in $\mathrm{HCV}$ monoinfected patients was predictive of sustained virological response (SVR) and proposed a threshold of $1755 \mu \mathrm{g} . \mathrm{h} / \mathrm{L}$ for the RBV plasma AUC from 0 to $4 \mathrm{~h}$ postdose to discriminate patients with subsequent SVR from those with non-response [17]. This is currently the only data that can be used to interpret early RBV exposure and determine the optimal dose to initiate treatment. The impact of the pharmacokinetic properties of RBV in HIV patients has not been fully investigated. As for HCV monoinfected patients, we know that a large inter-individual variability in RBV plasma concentrations exists in HIV-HCV coinfected patients and that RBV exposure is associated with both efficacy and anemia [8]. Moreover, the SVR rate is known to be lower in HIV$\mathrm{HCV}$ coinfected than in $\mathrm{HCV}$ monoinfected patients. One possible explanation could be that, as for other drugs, HIV infected patients present a lower bioavailability of RBV [18]. The aim of this study was to determine early plasma exposure evaluated by the $\mathrm{AUC}_{0-4 \mathrm{~h}}$ after a first dose of RBV in a population of HIV-HCV coinfected patients and to compare the results to those obtained in $\mathrm{HCV}$ monoinfected patients.

\section{Methods}

\section{Patients}

Consecutive patients seen by six physicians during a 12 months period for a chronic hepatitis $C$ infection (Edouard Herriot and Croix-Rousse hospitals, Lyon, France) and initiating a PEG-IFN/RBV therapy between February 2009 and February 2010 entered the study. RBV was taken with light breakfast or snack. Plasma AUC determination after a first dose of RBV $(600 \mathrm{mg})$ was obtained before therapy initiation as described by Loustaud-Ratti et al. [17] to evaluate RBV bioavailability. Treatment was then initiated using a weight-based RBV dose after possible adaptation following the AUC results. Patients with low ribavirin exposure (as assessed by AUC result) were usually treated with a $200 \mathrm{mg}$ higher ribavirin dose. Patients were divided into two groups according to their HIV status. To be included, patients had to have detectable HCV RNA, and for HIV-HCV coinfected patients to be on combined antiretroviral therapy (cART) for at least one month prior to RBV initiation. Patients with RBV treatment within the past three months were excluded. All patients gave their informed consent before they entered the study. Following characteristics were recorded at baseline (day of the first RBV dose intake): age, body weight, body mass index (BMI), creatinine level, glomerular filtration rate (GFR, estimated by Cockroft clearance and Modification of the Diet in Renal Disease (MDRD) formula), hemoglobin, aminotransferases, fibrosis stage, HCV genotype, HCVand HIV RNA quantification, CD4 level and antiretroviral drugs.

\section{Methods}

The plasma AUC was determined for each patient before the antiviral treatment or at the first day. Patients received a single RBV dose of $600 \mathrm{mg}$ (T0) and peripheral blood samples were collected before the administration to ensure undetectable baseline plasma RBV, and then $30 \mathrm{mn}, 1,2$ and 4 hours after RBV intake (T0.5, T1, T2 and T4). To avoid RBV exchange between plasma and red blood cells, samples were placed in ice immediately after withdrawal and centrifuged as soon as possible (maximum lag time was $1 \mathrm{~h}$ ). RBV plasma concentrations were measured using a validated High-Performance Liquid Chromatography-Diode Array Detector method [19]. This method is highly specific, sensible (limit of quantification $=0.05 \mathrm{mg} / \mathrm{L}$ ), and precise (total imprecision, calculated by measuring the coefficient of variation (CV) of the internal quality control values was less than $10 \%$ for concentrations from 0.20 to $5.00 \mathrm{mg} / \mathrm{L}$ ).

\section{Pharmacokinetic analysis}

RBV AUC was calculated using the Table Curve 2D software (Systat Software Inc). As a large variability of body weight (BW) was observed and that all patients received the same RBV first dose, AUC were also normalized as $\mathrm{AUC}_{0-4 \mathrm{~h}} /$ dose (in $\mathrm{mg} / \mathrm{BW}$ in $\mathrm{kg}$ ). Results of $\mathrm{AUC}$ and normalized AUC were analyzed according to the two groups defined by the HIV status.

\section{Statistical analysis}

All quantitative variables were expressed as median and range. Comparisons of data were made using the nonparametric Mann-Whitney test. Statistical analysis was performed using the Statistica ${ }^{\circ}$ software package (StatSoft Inc). A multivariate logistic regression analysis was conducted to identify factors potentially associated with RBV underexposure (defined by an AUC $<1755 \mu$ g.h/L). Variables significantly associated with RBV underexposure in univariate analysis and variables suspected to be associated with it, were included in the multivariate model. A p value below 0.05 was considered as statistically significant.

\section{Ethical considerations}

RBV pharmacokinetics monitoring is routinely performed in our unit for patients treated with PEG-IFN/RBV. This monitoring includes measurement of RBV AUC before therapy initiation and assessment of RBV plasma concentration during treatment. RBV monitoring is used to adapt 
RBV dose and to manage anemia. According to the French legislation (Public Health Code modified by the law no. 2004-806, 9 August 2004 and the Huriet-Sérusclat act 88-1138, 20 December 1988) and since this study was observational, no ethics committee approval was necessary.

\section{Results}

Eighty-six Caucasian patients with chronic hepatitis C entered the study. Among them, 62 were males (72\%) and 23 (27\%) were HIV-HCV coinfected. Most of them (85\%) were infected with HCV genotype 1 or 4 . Baseline characteristics are presented in Table 1.

Among HIV-HCV coinfected patients, 20/23 (87\%) had a negative HIV RNA viral load at baseline $(<50$ copies $/ \mathrm{mL}$ ) and $57 \%$ had a CD4 count above 500 cells $/ \mathrm{mm}^{3}$. Most of them received two nucleoside reverse transcriptase inhibitors (NRTIs) (22 patients): tenofovir and emtricitabine for 20 of them (91\%) and didanosine associated with stavudine or tenofovir for two. One patient received a cART regimen without NRTI. No patient received abacavir. Nucleoside treatment was associated with a protease inhibitor in 14 patients: seven patients received lopinavir, four darunavir, two atazanavir and one saquinavir. All these patients were also treated with ritonavir as a booster. Eight patients received a non-nucleoside reverse transcriptase inhibitor (NNRTI): four nevirapine, three efavirenz and one etravirine.

Finally, four patients received raltegravir, associated with a protease inhibitor regimen in three of them and with tenofovir and emtricitabine in one. One patient received maraviroc in association with a protease inhibitor, NNRTI and raltegravir.

Medians of $\mathrm{AUC}_{0-4 \mathrm{~h}}$ and $\mathrm{AUC}_{0-4 \mathrm{~h}}$ normalized to the first RBV dose expressed in mg/kg BW were $1469 \mu \mathrm{g} . \mathrm{h} / \mathrm{L}$ and $182(\mu \mathrm{g} . \mathrm{h} / \mathrm{L}) /(\mathrm{mg} / \mathrm{kg})$ respectively. According to the threshold of $1755 \mu \mathrm{g} . \mathrm{h} / \mathrm{L}$ defined in $\mathrm{HCV}$ monoinfected patients, 14/23 (61\%) coinfected patients were found to have an $\mathrm{AUC}_{0-4 \mathrm{~h}}$ below this value. No significant

Table 1 Main baseline characteristics of HCV monoinfected and HIV-HCV coinfected patients $(n=86)$

\begin{tabular}{|c|c|c|c|}
\hline Characteristics & $\mathrm{HCV}(n=63)$ & HIV-HCV $(n=23)$ & $p$ value \\
\hline Gender ratio (M/F) & 2.0 & 6.7 & 0.063 \\
\hline Age (years) & $50(23-74)$ & $46(35-60)$ & 0.066 \\
\hline Body weight (kg) & $75(41-130)$ & $69(52-96)$ & 0.032 \\
\hline Men body weight (kg) & $79(44-130)$ & $69(52-96)$ & 0.008 \\
\hline Body mass index (BMI) & $25.7(16.4-43.3)$ & $22.1(17.6-32.8)$ & 0.003 \\
\hline Men body mass index (BMI) & $25.8(18.4-43.3)$ & $22.2(17.6-32.8)$ & 0.002 \\
\hline Creatinine ( $\mu \mathrm{mol} / \mathrm{L})$ & $76(49-189)$ & $82(45-123)$ & 0.164 \\
\hline Cockroft clearance (mL/min) & $105.7(44-257.7)$ & $90.2(67.2-202.9)$ & 0.244 \\
\hline MDRD (mL/min) & $90.9(34.2-167.5)$ & $89.5(58.2-144.7)$ & 0.880 \\
\hline $\operatorname{ALT}(I U / m L)$ & $62(20-383)$ & $60.5(20-1492)$ & 0.853 \\
\hline AST (IU/mL) & $47(20-402)$ & $57(26-969)$ & 0.485 \\
\hline HCV RNA (log IU/mL) & $6.1(3.59-6.99)$ & $6.4(2.81-7.39)$ & 0.111 \\
\hline Hemoglobin level (g/dl) & $14.5(8.2-17.2)$ & $15.2(12.1-18.8)$ & 0.036 \\
\hline Men hemoglobin level ( $g / d l)$ & $15(8.3-17.2)$ & $15.2(12.1-18.8)$ & 0.239 \\
\hline HCV genotype n (\%) & & & 0.566 \\
\hline 1 & $48(76)$ & $14(61)$ & \\
\hline 2 & $2(3)$ & $1(4)$ & \\
\hline 3 & $6(10)$ & $4(17)$ & \\
\hline 4 & $7(11)$ & $4(17)$ & \\
\hline Fibrosis score (Metavir) n (\%) & & & 0.780 \\
\hline $0-2$ & $29(46)$ & $12(52)$ & \\
\hline $3-4$ & $34(54)$ & $11(48)$ & \\
\hline HCV treatment status at baseline $n(\%)$ & & & 0.434 \\
\hline HCV treatment naive & $19(30)$ & $9(41)$ & \\
\hline Nonresponders & $25(40)$ & $9(41)$ & \\
\hline Relapsers & $19(30)$ & $4(18)$ & \\
\hline
\end{tabular}

ALT, alanine aminotransferase; AST, aspartate aminotransferase; MDRD, Modification of the Diet in Renal Disease. Bold style indicates statistical significance. Quantitative variables are expressed as median and range. 
difference was found for cART type and duration, HIV viral load and $\mathrm{CD} 4$ level between the 2 sub-groups of HIV-HCV coinfected patients defined by this threshold (Table 2). All three patients found to have a detectable HIV RNA, had an $\mathrm{AUC}_{0-4 \mathrm{~h}}$ below $1755 \mu \mathrm{g} . \mathrm{h} / \mathrm{L}$. With regard to the immune status, $61 \%$ of patients had a CD4 level below the retained cutoff of $500 / \mathrm{mm}^{3}$. Interestingly, the $\mathrm{AUC}_{0-4 \mathrm{~h}}$ was significantly lower for these patients than for those with CD4 level greater than $500 / \mathrm{mm}^{3}$ with values of $1270 \mu \mathrm{g} . \mathrm{h} / \mathrm{L}$ and $1840 \mu \mathrm{g} . \mathrm{h} / \mathrm{L}$ respectively $(\mathrm{p}=$ 0.047). For these 2 sub-groups of coinfected patients, normalized AUC were 144 and $195(\mu \mathrm{g} . \mathrm{h} / \mathrm{L}) /(\mathrm{mg} / \mathrm{kg})$ but the difference did not reach statistical significance. Table 3 summarizes these results.

For the reference group of $\mathrm{HCV}$ monoinfected patients, median $\mathrm{AUC}_{0-4 \mathrm{~h}}$ and normalized $\mathrm{AUC}_{0-4 \mathrm{~h}}$ were $2030 \mu \mathrm{g} . \mathrm{h} / \mathrm{L}$ and $271 \mu \mathrm{g} . \mathrm{h} / \mathrm{L}$ respectively. In comparison to HIV-HCV coinfected patients, these two parameters were significantly higher $(\mathrm{p}=0.018$ and 0.001 , respectively). Sixty-eight percent of monoinfected patients had an $\mathrm{AUC}_{0-4 \mathrm{~h}}$ above the threshold of $1755 \mu \mathrm{g} . \mathrm{h} / \mathrm{L}$ vs $39 \%$ of HIV-HCV coinfected patients $(\mathrm{p}=0.014)$. The median $\mathrm{AUC}_{0-4 \mathrm{~h}}$ was slightly higher in naive $\mathrm{HCV}$ patients than in relapsers and non-responders $(2434 \mu \mathrm{g} . \mathrm{h} / \mathrm{L}, 2025 \mu \mathrm{g}$. $\mathrm{h} / \mathrm{L}$ and $1873 \mu \mathrm{g} . \mathrm{h} / \mathrm{L}$, respectively, although this difference did not reach statistical significance $(\mathrm{p}=0.165)$.

Different factors potentially associated with RBV pharmacokinetics variability were investigated. Except for body weight, BMI, and hemoglobin level, baseline characteristics did not differ between monoinfected and coinfected patients. Median body weight and BMI were lower in coinfected patients than in monoinfected ones $(69 \mathrm{~kg}$ vs $75 \mathrm{~kg}$, $\mathrm{p}=0.032$ and 22.1 vs $25.7, \mathrm{p}=0.003$, respectively). Conversely, hemoglobin level was lower in monoinfected patients (median $14.5 \mathrm{~g} / \mathrm{dl}$ ) than in coinfected patients $(15.2 \mathrm{~g} / \mathrm{dl} ; \mathrm{p}=0.036)$.
Multivariate logistic regression analysis indicated that presence of HIV coinfection (OR $=3.76,95 \% \mathrm{CI}$ [1.21-11.6]; $\mathrm{p}=0.022)$ and male gender $(\mathrm{OR}=4.59,95 \%$ CI $[1.15-18.3]$; $\mathrm{p}=0.031$ ) were independently associated with RBV underexposure (Table 4).

\section{Discussion}

Using the $\mathrm{AUC}_{0-4 \mathrm{~h}}$ method, our results clearly showed a plasma underexposure in HIV-HCV coinfected patients after a single dose intake of RBV in comparison with monoinfected patients. The pharmacokinetics of RBV is less documented in HIV-HCV coinfected patients than in monoinfected ones but some studies showed that the achievement of RBV cutoffs was a predictive factor of SVR independent of HIV coinfection [20,21]. The heterogeneity of our cohort of HIV-HCV coinfected patients was representative of a treated HIV population in a hospital environment (57\% with CD4 > 500 cells $/ \mathrm{mm}^{3}$; $87 \%$ with undetectable HIV viral load under HAART; patients mainly under 2 NRTIs +1 boosted protease inhibitor) [22]. The choice of $\mathrm{AUC}_{0-4 \mathrm{~h}}$ was made in accordance with the study of Loustaud-Ratti et al. for HCV monoinfected patients [17]. Indeed, the authors showed that the abbreviated $\mathrm{AUC}_{0-4 \mathrm{~h}}$ was highly correlated to the full $\mathrm{AUC}_{0-12 \mathrm{~h}}$ because it described the main inter-individual variability of RBV pharmacokinetic parameters (i.e. absorption and distribution phases). Interestingly in our study, more than $60 \%$ of coinfected patients had an $\mathrm{AUC}_{0-4 \mathrm{~h}}$ below the threshold of $1755 \mu \mathrm{g}$. $\mathrm{h} / \mathrm{L}$ defined as associated with SVR in HCV monoinfected patients [17]. In comparison, only $32 \%$ of monoinfected patients of our study had an $\mathrm{AUC}_{0-4 \mathrm{~h}}$ below this value. Demographic or biological parameters were collected in order to detect confounding factors that could affect differences in early RBV exposure between both populations. Some differences were found. The first of

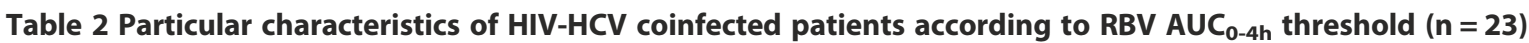

\begin{tabular}{|c|c|c|c|c|}
\hline & All $(n=23)$ & $\begin{array}{l}\text { RBV AUC } 0-4 \mathrm{~h}<1755 \mu \mathrm{g} \cdot \mathrm{h} / \mathrm{L} \\
(\mathrm{n}=14)\end{array}$ & $\begin{array}{l}\text { RBV AUC } 0-4 \mathrm{~h}>1755 \mu \mathrm{g} \cdot \mathrm{h} / \mathrm{L} \\
(\mathrm{n}=9)\end{array}$ & $\overline{p \text { value }}$ \\
\hline HIV RNA <50 copies/mL, n (\%) & $20(87)$ & $11(79)$ & $9(100)$ & 0.253 \\
\hline HIV RNA copies/mL & $50(20-9850)$ & $50(20-9850)$ & $50(40-50)$ & 0.687 \\
\hline CD4 (cells $/ \mathrm{mm}^{3}$ ) & $543(325-1067)$ & $498(325-993)$ & $543(368-1067)$ & 0.614 \\
\hline CD4\% & $30(10-48)$ & $29.5(10-48)$ & $32(27-45)$ & 0.174 \\
\hline Duration of HIV treatment (years) & $11(1-19)$ & $11(1-16)$ & $10(2-19)$ & 0.825 \\
\hline \multicolumn{5}{|l|}{ Antiretroviral therapy, n (\%) } \\
\hline Protease inhibitor & $14(61)$ & $7(50)$ & $7(78)$ & \\
\hline Nucleoside reverse transcriptase inhibitor (NRTI) & $21(91)$ & $13(93)$ & $8(89)$ & \\
\hline Non-nucleoside reverse transcriptase inhibitor (NNRTI) & $8(35)$ & $6(43)$ & $2(22)$ & \\
\hline Integrase inhibitor & $4(17)$ & $1(<1)$ & $3(33)$ & \\
\hline Receptor CCR5 inhibitor & $1(<1)$ & 0 & $1(11)$ & \\
\hline
\end{tabular}

Quantitative variables are expressed as median and range. 
Table 3 AUC $_{0-4 h}$ and normalized AUC $\mathrm{C}_{0-4 \mathrm{~h}}$ to RBV $600 \mathrm{mg} / \mathrm{body}$ weight

\begin{tabular}{|c|c|c|c|c|}
\hline & $\mathrm{HCV}(n=63)$ & HIV-HCV $(n=23)$ & & $p$ value \\
\hline$\overline{A \cup C_{0-4 h}}(\mu g . h / L)$ & $2030(851-7700)$ & $1469(936-3677)$ & & 0.018 \\
\hline Patients with $\mathrm{AUC}_{0-4 h}<1755$ (\%) & 32 & 61 & & 0.014 \\
\hline Men $A \cup C_{0-4 h}(\mu g . h / L)$ & $1875(850-7700)$ & $1414(1034-3677)$ & & 0.050 \\
\hline Men with $\mathrm{AUC}_{0-4 \mathrm{~h}}<1755$ (\%) & 43 & 65 & & 0.103 \\
\hline Normalized $\mathrm{AUC}_{0-4 \mathrm{~h}}(\mu \mathrm{g} . \mathrm{h} / \mathrm{L}) /(\mathrm{mg} / \mathrm{kg})$ & $271(82-1091)$ & $182(110-425)$ & & 0.001 \\
\hline \multirow[t]{2}{*}{ Men normalized $\mathrm{AUC}_{0-4 \mathrm{~h}}(\mu \mathrm{g} . \mathrm{h} / \mathrm{L}) /(\mathrm{mg} / \mathrm{kg})$} & $266(82-1091)$ & $173(110-425)$ & & 0.004 \\
\hline & & $\mathrm{CD} 4<500$ & $\mathrm{CD} 4 \geq 500$ & \\
\hline$A \cup C_{0-4 h}$ & & $1270(936-2792)$ & $1840(1280-3677)$ & 0.047 \\
\hline Normalized $A \cup C_{0-4 h}$ & & $144(110-425)$ & $195(154-349)$ & 0.108 \\
\hline
\end{tabular}

Quantitative variables are expressed as median and range. Bold style indicates statistical significance.

them was a body weight significantly lower for coinfected patients. As the initial RBV dose was the same (600 mg) for all patients, irrespectively of this parameter, early exposure was normalized for RBV dose expressed as $\mathrm{mg} / \mathrm{kg}$ $\mathrm{BW}$. Normalized $\mathrm{AUC}_{0-4 \mathrm{~h}}$ remained significantly different between both groups. In addition, hemoglobin level was higher in coinfected than in monoinfected patients. It is well known that RBV is highly concentrated in red blood cells [23], but this parameter was not expected to influence $\mathrm{AUC}_{0-4 \mathrm{~h}}$ which was determined after a single dose of RBV. Among other parameters known to have an influence on RBV exposure is the renal function, but neither median baseline serum creatinine, nor estimated glomerular filtration rate (GFR) calculated by Cockroft-Gault equation or MDRD formula, differed significantly between both groups (Table 1). We have determined early RBV exposure regardless of $\mathrm{HCV}$ genotype as no difference was observed in the genotype distribution in each of the two populations of this study and because we wanted to evaluate early bioavailability of RBV independently of the subsequent treatment response. In the study by LoustaudRatti et al. the population was exclusively constituted of monoinfected HCV genotype 1 patients. This is the main difference with our study in which genotypes 1 to 4 were present but with a majority of genotype 1 . Indeed, except for this parameter and for the distribution of fibrosis score, baseline characteristics were similar in both studies. However, $32 \%$ of our HCV monoinfected patients had an $\mathrm{AUC}_{0-4 \mathrm{~h}}$ below the $1755 \mu \mathrm{g} . \mathrm{h} / \mathrm{L}$ threshold compared with $58 \%$ in this historical study. This difference could be explained by the presence of patients infected by HCV genotype 2, 3 or 4 because only two of these 15 patients had an $\mathrm{AUC}_{0-4 \mathrm{~h}}$ below this threshold. Finally, we found a strong gender ratio in favor of male patients in our coinfected population. In order to estimate if gender could affect RBV exposure, we compared parameters which were statistically different in the whole population. For body weight the significant difference was even more important and as expected, this parameter was lower in coinfected patients (Table 1). Hence the interest of the AUC normalized to the first RBV dose deletes the weight effect. Conversely, differences in hemoglobin level were no longer significant due to the higher proportion of women in the monoinfected group. In spite of the reduced number of patients, the difference of $\mathrm{AUC}_{0-4 \mathrm{~h}}$ or normalized $\mathrm{AUC}_{0-4 \mathrm{~h}}$ between monoinfected and coinfected male patients was statistically significant, and the proportion of AUC under the $1755 \mu \mathrm{g} . \mathrm{h} / \mathrm{L}$ threshold remained high. No other differences in demographic or biological characteristics were found between the two populations of this study.

Given that there was a strong gender ratio in favor of male patients and in order to see if gender could affect

Table 4 Univariate and multivariate logistic regression analysis to identify factors potentially associated with ribavirin underexposure (defined by an AUC $<1755 \mu \mathrm{g} . \mathrm{h} / \mathrm{L}$ )

\begin{tabular}{|c|c|c|c|c|}
\hline & \multicolumn{2}{|c|}{ Univariate analysis } & \multicolumn{2}{|c|}{ Multivariate analysis } \\
\hline & OR $(95 \% \mathrm{Cl})$ & $p$ & OR $(95 \% \mathrm{Cl})$ & $p$ \\
\hline HIV coinfection (yes vs no) & $3.34(1.24-9.01)$ & 0.017 & $3.76(1.21-11.6)$ & 0.022 \\
\hline Gender (male vs female) & $7.00(1.89-25.9)$ & 0.004 & $4.59(1.15-18.3)$ & 0.031 \\
\hline Weight & $1.03(0.99-1.06)$ & 0.067 & $1.03(0.99-1.08)$ & 0.142 \\
\hline Age & $0.97(0.93-1.01)$ & 0.160 & - & - \\
\hline MDRD & $1.00(0.98-1.02)$ & 0.803 & - & - \\
\hline Cockroft & $1.01(0.99-1.02)$ & 0.145 & $1.00(0.98-1.02)$ & 0.927 \\
\hline
\end{tabular}

Bold style indicates statistical significance. 
our results, we compared $\mathrm{AUC}_{0-4 \mathrm{~h}}$ between monoinfected and coinfected male patients. It is noteworthy that $43 \%$ of monoinfected and $65 \%$ of coinfected male patients had $\mathrm{AUC}_{0-4 h}$ below the $1755 \mu \mathrm{g} . \mathrm{h} / \mathrm{L}$ threshold, although this difference did not reach statistical significance $(p=0.103)$. As expected, among HCV monoinfected patients, the $\mathrm{AUC}_{0-4 \mathrm{~h}}$ was slightly higher in naive patients than in relapsers and non-responders to a previous treatment although this difference did not reach statistical significance probably because of a limited number of patients in each subgroup.

Unexpectedly, RBV plasma underexposure seems to be associated with the immunological level of HIV patients. RBV exposure was indeed better if CD4 cell count was greater than $500 / \mathrm{mm}^{3}$. In the RIBAVIC study, using PEGIFN/RBV therapy in HIV co-infected patients, a trend for a lower SVR was noted in patients with a CD4 cell count under 500 versus patients upper this threshold $(21 \%$ vs $33 \%$, respectively; $\mathrm{p}=0.051$ ) [24]. Then, in the PRESCO trial, a higher dosing of ribavirin (weight-based dosing with 1000 to $1200 \mathrm{mg}$ ) was associated with better SVR rates but higher risk of anemia [25]. In the present study, when the immunorestoration under cART was considered complete, i.e. with a CD4 cell count $>500 / \mathrm{mm}^{3}$, RBV exposure was similar in this HIV sub-group in comparison with $\mathrm{HCV}$ monoinfected population.

Food intake is known to potentially impact RBV bioavailability. Both the $\mathrm{AUC}_{\mathrm{tf}}$ (from time zero to the time of the final quantifiable sample) and $C_{\max }$ of a single oral dose of ribavirin were indeed shown to be increased by co-administration of a high fat meal [26]. However, in the present study all patients received RBV with light breakfast or snack which suggests no bias between mono- and coinfected patients.

\section{Conclusion}

In conclusion, HIV-HCV coinfected patients present a lower RBV exposure which could at least in part explain the lower response rate of these patients to HCV treatment. This hypothesis should be further investigated on a larger number of coinfected patients focusing on the immune status of these patients. In the past, recommendations were to use low dose of RBV in HIV patients in order to avoid toxicity associated with antiretroviral drugs, such as zidovudine, stavudine or didanosine $[27,28]$. However, these drugs are progressively neglected to the benefit of less cytotoxic new antiretroviral drugs. So, higher doses of RBV can be used to improve SVR in coinfected patients, as suggested in several studies [7,29]. Measurement of early RBV exposure by determination of $\mathrm{AUC}_{0-4 \mathrm{~h}}$ possibly followed by RBV dose adjustment could help in optimizing antiviral therapy in HIV-HCV coinfected patients, particularly in the more immunosuppressed ones because RBV underexposure was noted in this specific sub-group.

\section{Abbreviations}

AUC: Area under the curve; BMI: Body mass index; CART: Effective combination antiretroviral therapy; GFR: Glomerular filtration rate; HAART: Highly active antiretroviral therapy; HCV: Hepatitis C virus; HIV: Human immudeficiency virus; MDRD: Modification of the diet in renal disease; RBV: Ribavirin; SVR: Sustained virological response.

\section{Competing interests}

Fabien Zoulim received consulting/speaker fees from Gilead Science, Bristol Myers Squibb, and Roche. François Bailly received speaker fees from Janssen. The other authors have no conflict of interests to declare. No financial support.

\section{Authors' contributions}

$F B, P P, M M, F P, F Z, M C G$ participated in the conception and design of the study. GH, FB, EP, PP, PM, MM, FP, PC, JML participated in data collection. EP and PP performed the statistical analysis. GH, FB, EP, PP, PM and MCG helped to draft the manuscript. All authors read and approved the final version of the manuscript.

\section{Acknowledgments}

The authors gratefully thank Laurent Cotte, Philippe Lack, François Jeanblanc, Djamila Makhloufi, Sylvie Radenne, and Isabelle Schlienger for their contribution in this study.

\section{Author details}

${ }^{1}$ Department of Hepatology, Hôpital de la Croix-Rousse, Hospices Civils de Lyon, 103 grande rue de la Croix-Rousse, 69004 Lyon, France. 'Université de Médicine et Pharmacie "Iuliu Hatieganu", Cluj-Napoca, Romania. ${ }^{3}$ INSERM U1052, Lyon, France. ${ }^{4}$ Université Lyon I, Lyon, France. ${ }^{5}$ Pharmacology, Hôpital Edouard Herriot, Hospices Civils de Lyon, Lyon, France. ${ }^{6}$ Departement of Infectious Diseases, Hôpital de la Croix-Rousse, Hospices Civils de Lyon, Lyon, France. ${ }^{7}$ Department of Immunology, Hôpital Edouard Herriot, Hospices Civils de Lyon, Lyon, France.

Received: 26 November 2013 Accepted: 14 March 2014

Published: 20 March 2014

\section{References}

1. Sherman KE, Rouster SD, Chung RT, Rajicic N: Hepatitis C Virus prevalence among patients infected with Human Immunodeficiency Virus: a cross-sectional analysis of the US adult AIDS Clinical Trials Group. Clin Infect Dis 2002, 34(6):831-837.

2. Sulkowski MS, Moore RD, Mehta SH, Chaisson RE, Thomas DL: Hepatitis C and progression of HIV disease. JAMA 2002, 288(2):199-206.

3. Thomas DL, Vlahov D, Solomon L, Cohn S, Taylor E, Garfein R, Nelson KE: Correlates of hepatitis $C$ virus infections among injection drug users. Medicine (Baltimore) 1995, 74(4):212-220.

4. Rosenthal E, Poiree M, Pradier C, Perronne C, Salmon-Ceron D, Geffray L, Myers RP, Morlat P, Pialoux G, Pol S, Cacoub P: Mortality due to hepatitis C-related liver disease in HIV-infected patients in France (Mortavic 2001 study). AIDS 2003, 17(12):1803-1809.

5. Soriano V, Martin-Carbonero L, Garcia-Samaniego J, Puoti M: Mortality due to chronic viral liver disease among patients infected with human immunodeficiency virus. Clin Infect Dis 2001, 33(10):1793-1795.

6. Clinical Practice Guidelines EASL: Management of hepatitis $C$ virus infection. J Hepatol 2014, 60(2):392-420.

7. Lindahl K, Stahle L, Bruchfeld A, Schvarcz R: High-dose ribavirin in combination with standard dose peginterferon for treatment of patients with chronic hepatitis C. Hepatology 2005, 41(2):275-279.

8. Rendon AL, Nunez M, Romero M, Barreiro P, Martin-Carbonero L, Garcia-Samaniego J, Jimenez-Nacher I, Gonzalez-Lahoz J, Soriano V: Early monitoring of ribavirin plasma concentrations may predict anemia and early virologic response in HIV/hepatitis $C$ virus-coinfected patients. J Acquir Immune Defic Syndr 2005, 39(4):401-405.

9. Crespo M, Pou L, Esteban Jl, Falco V, Ribera E, Lopez R, Sauleda S, Curran A, Villar Del Saz S, Feijoo M, Ocana I, Pahissa A: Early monitoring of ribavirin serum concentration is not useful to optimize hepatitis $C$ virus treatment in HIV-coinfected patients. Antivir Ther 2007, 12(8):1217-1223.

10. Jen J, Laughlin M, Chung C, Heft S, Affrime MB, Gupta SK, Glue P, Hajian G: Ribavirin dosing in chronic hepatitis C: application of population 
pharmacokinetic-pharmacodynamic models. Clin Pharmacol Ther 2002, 72(4):349-361.

11. Glue P: The clinical pharmacology of ribavirin. Semin Liver Dis 1999 19(Suppl 1):17-24.

12. Jen JF, Glue P, Gupta S, Zambas D, Hajian G: Population pharmacokinetic and pharmacodynamic analysis of ribavirin in patients with chronic hepatitis C. Ther Drug Monit 2000, 22(5):555-565.

13. Larrat S, Stanke-Labesque F, Plages A, Zarski JP, Bessard G, Souvignet C: Ribavirin quantification in combination treatment of chronic hepatitis $C$. Antimicrob Agents Chemother 2003, 47(1):124-129.

14. Wade JR, Snoeck E, Duff F, Lamb M, Jorga K: Pharmacokinetics of ribavirin in patients with hepatitis C virus. Br J Clin Pharmacol 2006, 62(6):710-714.

15. Bruchfeld A, Lindahl K, Schvarcz R, Stahle L: Dosage of ribavirin in patients with hepatitis $C$ should be based on renal function: a population pharmacokinetic analysis. Ther Drug Monit 2002, 24(6):701-708.

16. Dahari H, Markatou M, Zeremski M, Haller I, Ribeiro RM, Licholai T, Perelson AS, Talal AH: Early ribavirin pharmacokinetics, HCV RNA and alanine aminotransferase kinetics in HIV/HCV co-infected patients during treatment with pegylated interferon and ribavirin. J Hepatol 2007, 47(1):23-30.

17. Loustaud-Ratti V, Alain S, Rousseau A, Hubert IF, Sauvage FL, Marquet $P$, Denis F, Lunel F, Cales P, Lefebvre A, Fauchais AL, Liozon E, Vidal E: Ribavirin exposure after the first dose is predictive of sustained virological response in chronic hepatitis C. Hepatology 2008, 47(5):1453-1461.

18. Arab-Alameddine M, Fayet-Mello A, Lubomirov R, Neely M, di lulio J, Owen A, Boffito M, Cavassini M, Gunthard HF, Rentsch K, Buclin T, Aouri M, Telenti A, Decosterd LA, Rotger M, Csajka C: Population pharmacokinetic analysis and pharmacogenetics of raltegravir in HIV-positive and healthy individuals. Antimicrob Agents Chemother 2012, 56(6):2959-2966.

19. Sauvage FL, Stanke-Labesque F, Gagnieu MC, Jourdil JF, Babany G, Marquet P: Feasibility of ribavirin therapeutic drug monitoring in hepatitis $\mathrm{C}$. Ther Drug Monit 2009, 31(3):374-381.

20. Aguilar Marucco D, Gonzalez De Requena D, Bonora S, Tettoni C, Bonasso M, De Blasi T, D'Avolio A, Sciandra M, Siccardi M, Baietto L, Trentini L, Sinicco A, Cariti G, Di Perri G: The use of trough ribavirin concentration to predict sustained virological response and haematological toxicity in HIV/HCVco-infected patients treated with ribavirin and pegylated interferon. J Antimicrob Chemother 2008, 61(4):919-924.

21. Piedoux S, Monnet E, Piroth L, Montange D, Royer B, Thevenot T, Kantelip JP, Di Martino V, Muret P: Relative impact of ribavirin monitoring and HIV coinfection on sustained virological response in patients with chronic hepatitis C. Antivir Ther 2011, 16(8):1317-1326.

22. Sulkowski MS, Benhamou Y: Therapeutic issues in HIV/HCV-coinfected patients. J Viral Hepat 2007, 14(6):371-386.

23. Souvignet C, Maynard M, Gagnieu MC, Trepo C: Ribavirin in combination therapy for HCV chronic infection in HIV patients: how to win the war after winning the first battle? J Hepatol 2007, 47(1):1-3.

24. Carrat F, Bani-Sadr F, Pol S, Rosenthal E, Lunel-Fabiani F, Benzekri A, Morand P, Goujard C, Pialoux G, Piroth L, Salmon-Ceron D, Degott C, Cacoub P, Perronne C: Pegylated interferon alfa-2 $b$ vs standard interferon alfa- $2 \mathrm{~b}$, plus ribavirin, for chronic hepatitis $\mathrm{C}$ in HIV-infected patients: a randomized controlled trial. JAMA 2004, 292(23):2839-2848.

25. Nunez M, Miralles C, Berdun MA, Losada E, Aguirrebengoa K, Ocampo A, Arazo P, Cervantes M, de Los SI, San Joaquin I, Echeverria S, Galindo MJ, Asensi V, Barreiro P, Sola J, Hernandez-Burruezo JJ, Guardiola JM, Romero M, Garcia-Samaniego J, Soriano V: Role of weight-based ribavirin dosing and extended duration of therapy in chronic hepatitis C in HIV-infected patients: the PRESCO trial. AIDS Res Hum Retroviruses 2007, 23(8):972-982.

26. Ribavirin - Summary of Product Characteristics - European Medicines Agency. http://www.ema.europa.eu/docs/en_GB/document_library/EPAR__Product Information/human/000246/WC500048210.pdf (visited February 2014).

27. Lafeuillade A, Hittinger G, Chadapaud S: Increased mitochondrial toxicity with ribavirin in HIV/HCV coinfection. Lancet 2001, 357(9252):280-281.
28. Moreno A, Quereda C, Moreno L, Perez-Elias MJ, Muriel A, Casado JL, Antela A, Dronda F, Navas E, Barcena R, Moreno S: High rate of didanosine-related mitochondrial toxicity in HIV/HCV-coinfected patients receiving ribavirin. Antivir Ther 2004, 9(1):133-138

29. Soriano V, Puoti M, Sulkowski M, Cargnel A, Benhamou Y, Peters M, Mauss S, Brau N, Hatzakis A, Pol S, Rockstroh J: Care of patients coinfected with HIV and hepatitis C virus: 2007 updated recommendations from the HCV-HIV International Panel. AIDS 2007, 21(9):1073-1089.

doi:10.1186/1471-2334-14-150

Cite this article as: Hatu et al.: Lower ribavirin biodisponibility in patients with HIV-HCV coinfection in comparison with HCV monoinfected patients. BMC Infectious Diseases 2014 14:150.

\section{Submit your next manuscript to BioMed Central and take full advantage of:}

- Convenient online submission

- Thorough peer review

- No space constraints or color figure charges

- Immediate publication on acceptance

- Inclusion in PubMed, CAS, Scopus and Google Scholar

- Research which is freely available for redistribution

Submit your manuscript at www.biomedcentral.com/submit
C BioMed Central 